\title{
PUNISHING THE ALIEN: THE SENTENCING OF FOREIGN OFFENDERS IN SLOVENIA
}

\author{
Mojca M. PLESNIČAR', Jaka KUKAVICA"
}

COBISS 1.01

\section{ABSTRACT \\ Punishing the Alien: The Sentencing of Foreign Offenders in Slovenia}

The authors examine the question of foreignness, which appears in many shades; citizenship is thus just one of the many aspects contributing to society's stance on 'foreignness'. After sketching the current prison situation in Europe, the authors analyse the situation of foreigners in the Slovenian criminal justice system. On the one hand, we can perceive a general turn towards harsher treatment of foreign offenders - there have been more convictions and more foreigners in prison recently. However, a more detailed analysis shows that with regard to cases of homicide, foreigners may even be receiving more lenient sentences compared to Slovenian citizens.

KEY WORDS: foreigners, prison, criminal justice, court, sentencing

\section{IZVLEČEK}

\section{Kaznovanje tujcev: Kaznovanje tujih storilcev kaznivih dejanj v Sloveniji}

Avtorja se uvodoma ukvarjata z vprašanjem »tujosti«, ki se pojavlja v več intenzitetah: državljanstvo posameznika je le eden od dejavnikov, ki vplivajo na njegovo družbeno sprejemanje ali zavračanje. Po pregledu stanja $v$ evropskih zaporih avtorja $v$ osrednjem delu analizirata položaj tujcev v slovenskem kazenskopravnem sistemu, kjer je mogoče zaznati zaostrovanje pri obravnavi tujcev - več obsodb in več tujcev v zaporih v zadnjih letih. Temu nasprotne rezultate pa pokaže podrobnejši pregled kaznivega dejanja umora (in uboja), v katerem avtorja ugotavljata, da je kaznovanje tujcev celo manj punitivno kot kaznovanje domačih državljanov in za to ponudita nekaj morebitnih razlag.

KLJUČNE BESEDE: tujci, zapor, kazenskopravni sistem, sodišče, kaznovanje

PhD in Criminology, Assistant Professor and Associate Researcher at the Institute of Criminology, University of Ljubljana, Poljanski nasip 2, SI-1000 Ljubljana; mojca.plesnicar@pf.uni-lj.si

\| LL.M., PhD Candidate at European University Institute; jaka.kukavica@eui.eu - The authors would like to thank Marko Drobnjak for his help with statistics, and Milena Tripković for helpful comments on an earlier draft. 


\section{INTRODUCTION}

Crimmigration has become an increasingly important field in recent years, both in real life and in academic research. However, different authors mean different things when using the term, with one unifying aspect being the phenomenon of the merging of criminal and migration laws (e.g. Hernandez 2014; Stumpf 2006).

Even though migration has been an essential feature of human society since its beginnings, its presence in the public discourse has fluctuated, with highs and lows regarding the popularity of the topic. It seems we are currently at one of the highs, with a pronounced focus on migration and its many aspects (Melossi 2003).

One of the associations most commonly assumed in contemporary public discourse and often acted upon very quickly is that with crime - the idea of the "deviant migrant" is a strong and persistent one (Franko 2007). In order to better analyse it and often disprove some "common sense" assumptions, increasingly detailed and thoughtful literature on various issues and in different global settings has emerged (Bosworth, Hasselberg, Turnbull 2016; Franko 2014; Franko, Bosworth 2013; Hernandez 2014, 2015; Kogovšek Šalamon 2017; Stumpf 2006). This paper will address just one of the many facets of crimmigration, and that is the more traditional one: we will look at how foreign offenders are treated within national criminal justice systems as a consequence of committing an offence (Delgrande, Aebi 2009; Melossi 2003; Ugelvik 2014). While acknowledging this is just one feature of a multifaceted issue, and just one aspect of where the notion of penality crosses with the notion of being an immigrant, we believe it is an important one. Moreover, it is one on which the literature is rather scarce and would warrant more research (Ugelvik 2014).

In the paper, we will first deal with the concept of "foreignness" and define what we will refer to when using it throughout the text. We will then focus on the situation in Europe and look at how foreign nationals are treated by European countries, as well as seek explanations for their practices. The case of Slovenia will be discussed in more detail.

\section{DEGREES OF FOREIGNNESS}

The term foreign offender may not always mean the same thing to different people and in different contexts (Delgrande, Aebi 2009). When using it in this article, we refer to foreign nationals, i.e. people who do not have citizenship in the country in whose criminal justice system they are prosecuted (see also Ugelvik 2014). Other terms may be used to describe this: "non-citizen" could, for example, be a more precise option, but we feel the notion of "foreignness" is better encapsulated in the term foreign offender. Alien, the term used in the title of this article, is also occasionally used in crimmigration discourse, perhaps to emphasize how distant and detached discussions on foreigners may become and illuminate explicit shades of alienation in the 
managing of migration (Franko 2007; Hudson 2006). Incidentally, legislation perhaps anachronistically often uses the term as well: the Slovenian statute regulating the status of foreigners in Slovenia was until recently officially translated into English as the Aliens Act, like those in Sweden, Finland and Ireland, or the famous British Aliens Act of 1905 (Vincenzi 1985). The term has strong political connotations and has been repeatedly used in the USA by the Trump administration in recent discussions on immigrants, often coupled with the adjective 'criminal' to coin the collocation 'criminal alien' (Caldwell 2016), accidentally evoking Lombroso's classical notion of criminality.

A second concern is whether it is reasonable to discuss foreignness in the sense of 'non-citizenship'. Foreignness may easily be reconciled with the concept of 'otherness' (Bauman 1997; Franko 2007; Melossi 2003) and tied to contemporary ideas of the 'criminology of the other' (Franko 2007; Garland 2001). These have been explored in the general context of contemporary society, before the topic of crimmigration burst to the forefront of criminological inquiry, however, they can account for many of the present developments in this area (Franko 2007; Welch, Schuster 2005). One of the main features of the criminology of the other and the way it ties into the culture of control is the manner in which it transcends classical notions of correcting and (re) integrating criminals into the non-deviant majority, and instead offers the ideology of social control and (permanent?) exclusion. It allows society to relinquish its 'duty' to (re)include and grants it a right to exclude in its stead, using safety and community as excuses (Garland 2001).

Not only do foreigners fit into this framework rather nicely, as indicated by other authors (Franko 2007; Hudson 2003; Welch, Schuster 2005), but some suggest they are taking the place of other traditional groups of "others" - such as the socially disadvantaged (Bourdieu 1999 in Franko 2007). Moreover, Wacquant (1999) suggests foreigners in the European context may be taking up the outcast role carried by black people in the US.

Finally, while having or not having citizenship is a precise and unambiguous matter, foreignness is not. "The 'foreignness' of foreign nationals is not a simple 'yes or no' question: there may be degrees of 'foreignness' that results in different experiences for different groups of foreign national prisoners" (Ugelvik 2014: 114). In discussing this notion Ugelvik gives the example of Scandinavian yet foreign-national prisoners who 'look' Norwegian and are treated accordingly in the Norwegian criminal justice system, contrasted to Norwegian citizens who are seen as racially and culturally different, and are often subjected to harsher treatment despite their citizenship.

We can offer an additional, perhaps slightly more complicated example from Slovenia. As the northernmost and most developed of the ex-Yugoslav republics, it received a steady influx of then-nationals from other Yugoslav republics throughout the existence of the federal state. This resulted in sizable Serbian, Croatian and

1 Aliens Act - consolidated text, Official Gazette of the Republic of Slovenia, No 64/09, 1999. A new law has since been passed and its English translation is the Foreigners Act, Official Gazette of the Republic of Slovenia, No 1/18, 2011. 
Bosnian minorities, composed of people who decided to remain in Slovenia. These same countries continued to make up the large majority of countries of origin of immigrants coming to Slovenia post-independence (after 1991). This has two important consequences for our discussion. Firstly, the vast majority of contemporary immigrants are therefore culturally and ethnically identical to their predecessors, who have now become citizens. While their citizenship is now not disputed (although for some of them there was a long period after independence when it was, see Kogovšek Šalamon, 2016), their 'foreignness', on the other hand, is not quite as clear and by no means a 'yes or no' issue (cf. Bučar Ručman 2015).

Secondly, regardless of how we understand and differentiate between the two groups of Balkan immigrants (citizens and non-citizens), the two are distinctly different from the contemporary idea of the dangerous migrant present in the public discourse, which would typically entail a young Muslim brown or black male.

The idea is so pervasive as to counter and even consume the idea of the hardened violent male criminal (another 'other' commonly feared and imagined), as witnessed by contemporary media reports. At the time of writing, for example, one of the right-leaning Slovenian tabloids published a controversial cover depicting a white woman being groped by multiple black hands and claiming migrants are bringing "a culture of rape" to the country. The instance serves as a good example of how foreignness (depicted here by blackness) is conflated with deviance and criminality (e.g. through the use of the notion of rape) (Franko 2007; Melossi 2003; see also Vezovnik 2017). Any instance where such fears are materialized, and a migrant is actually found guilty of a crime, serves as reinforcement and confirmation of these assumptions. As Melossi (2003: 391) succinctly puts it: "[t]he stranger will be found doubly guilty, for his strangeness and for his deviance, already implicit and wholly predictable in his being a stranger".2

The majority of migrants in Slovenia, however, do not fit into this narrative, and although they are understood as culturally and ethnically different, when compared to these new narratives on migrants they seem much more similar to the Slovenian "us", a characteristic reinforced by our shared history and traditional ties with the southern countries. It is interesting to note that the contemporary public discourse rarely includes these migrants when discussing "foreigners" and "foreignness".

\section{PUNISHING FOREIGNERS}

Putting these nuances aside for a moment, we wish to briefly address how the question of 'being foreign' in its narrow citizenship sense may be important with regard to punishment as a response to a criminal offence. We have discussed the broader

2 The same type of double deviance is attributed to female criminals, as noted by Lombroso and Ferrero (2004) in their study on female criminality. 
questions of the idea of 'otherness' that come into play in punishment in the previous section, so we would like to be more specific here and look at the relationship between 'foreignness' and sentencing.

Many theories have attempted to explain differences in sentencing outcomes with regard to various personal circumstances of the offender, most often focusing on race and gender (Engen, Steen, Bridges 2002; Everett, Wojtkiewicz 2002; Holmberg, Kyvsgaard 2003; Mitchell 2005; Mustard 2001; Spohn 2013; Welch, Spohn, Gruhl 1985). These theoretical perspectives have not often included the offender's citizenship and its effect on the sentencing process. We acknowledge that citizenship might have a lesser effect on decision-making than race or ethnicity. As Ugelvik's (2014) abovementioned example clearly shows, being a Norwegian citizen is not the same as being a Norwegian. However, we believe that some important parallels do exist and are worth exploring.

Nearly all recent scholarly inquiries into sentencing practices in Europe and in North America have interpreted their results in light of the focal concerns perspective (Hartley, Armendariz 2011; Johnson, Van Wingerden, Nieuwbeerta 2010; Light, Massoglia, King 2014; Wermink, Johnson, Nieuwbeerta, de Keijser 2015; Wingerden 2014; Wolfe, Pyrooz, Spohn 2011; Wu, D’Angelo 2014). Developed by Steffensmeier, Kramer, and Streifel (1993) and Steffensmeier, Ulmer, and Kramer (1998), the theory posits that in reaching a sentencing decision, judges are influenced by three focal concerns. First, judges consider the offender's blameworthiness, which includes the offender's role in the offence, his potential criminal history, and prior victimisation by third parties. Second, they seek to protect the community from the risk of reoffending and recidivism. Third, judges consider organisational and individual practical constraints and consequences, such as prison crowding, courtroom agenda, or the health and family ties of the offender.

Steffensmeier et al. (1998), as well as most other authors who rely on focal concerns, complement and provide depth to this perspective with the views of attribution theorists (Fontaine, Emily 1978; Hawkins 1981; Shaver 1975), who maintain that judges make determinations about the three focal concerns on the basis of insufficient and imperfect information. To fill this data gap, judges will resort to their pre-existing mental schemes and stereotypes. They complete their understanding of the case by attributing them to individual offenders based on characteristics such as race, ethnicity, gender, or citizenship (Albonetti 1991, 1997; Everett, Wojtkiewicz 2002; Hartley, Armendariz 2011; Johnson et al. 2010; Steffensmeier et al. 1998; Wingerden 2014; Wolfe et al. 2011).

Focal concerns and attribution theories aim to explain a sentencing decision of any given judge in an individual case. However, academics have also sought to make sense of disparities in sentencing outcomes in the aggregate and explain why entire groups of people are treated differently, often less favourably, both at trial and in the criminal justice system more generally. Conflict theory, arguing that criminal justice is likely to treat marginalized groups and those far removed from power more severely, 
has been used to suggest that minority racial and ethnic groups are likely to be treated more harshly (Bridges et al. 1987; Everett, Wojtkiewicz 2002; Quinney 1973). This same conclusion can also be reached through social identity theory, which posits that we split society into the 'in-group' (us) and the 'out-group' (them); this distinction forms the basis for discrimination against the out-group and positive behaviour towards the in-group (Fishman et al. 2006; Tajfel, Turner 1979). Somewhat similarly, group threat theory argues that as the size of the minority group increases, the dominant majority feels economically, politically, and culturally threatened. As a result, it will intensify its efforts to regain and entrench social control and eliminate the threat it perceives from the growing minority (Blalock 1967; Light et al. 2014; Wu, D'Angelo 2014).

However, when looking at the empirical evidence, the picture is less clear than expected. In the USA, only a handful of studies have unequivocally showed that being a non-citizen resulted in a more severe sentencing outcome. Light et al. (2014), for instance, found that there was a 'citizenship sentencing penalty' in federal criminal cases which is significantly larger than the infamous 'black' or 'Hispanic' penalty. They discovered that non-citizens, both documented and undocumented, were more than four times more likely to be sentenced to prison and received longer sentences than US citizen offenders. Similarly, Mustard (2001) found that citizens in federal cases are more likely to receive no sentence, and if sentenced they receive sentences that are about 1.7 months shorter, are more likely to receive downward departures, and receive more substantial downward departures than non-citizens. The US Sentencing Commission (2010) also found that most multivariate regression models showed that in most parts of the period of observation, non-citizens were punished more severely than US citizens in federal cases.

Other studies have provided more ambiguous and mixed results. Albonetti (1997) found that in federal drug cases in 1991-1992, having foreign citizenship significantly increased sentence severity for black and Hispanic defendants, but not for white offenders. Also in federal drug cases, but covering the period from 1996-1999, Demuth (2002) discovered that while the difference in sentence length between US citizens and non-citizens is insignificant, non-citizen offenders who are documented aliens are $30 \%$ more likely to be imprisoned, and undocumented aliens are $44 \%$ more likely to be imprisoned. A similar conclusion was reached by Wolfe et al. (2011), who showed that documented and undocumented non-citizens were $37 \%$ and 9.5 times, respectively, more likely to be sentenced to prison in federal criminal cases. However, citizenship had no effect on sentence length for documented non-citizens but resulted in $5 \%$ shorter prison sentences for undocumented non-citizens compared to US citizens.

A study conducted by Hartley and Armendariz (2011) focusing on sentences in federal narcotics cases in five southern border districts of the USA in 2008 is indicative and symbolic of the inconclusiveness of sentencing research and citizenship. Their results suggest that the effect of offenders' citizenship on sentencing outcomes varied significantly and substantially from district to district, and from narcotic to 
narcotic. Wu and D'Angelo (2014) found that the effect citizenship has on sentencing in federal cases also depends on the type of offence. Their results indicate that non-citizens receive significantly shorter sentences for firearms offences, significantly longer sentences for immigration offences, and found no significant difference in sentence length between citizens and non-citizens for drug, violent, property, and other offences. Finally, in U.S. District Courts for Minnesota, Nebraska, and Southern lowa, Wu and Spohn (2010) found no significant effect of citizenship of the offender on the length of the sentence.

In Europe, most of the work on sentencing has been conducted in the Netherlands. Johnson et al. (2010), for instance, found that European and non-European non-citizens who target Dutch victims receive significantly longer sentences than Dutch offenders in similar situations. Similar results were also obtained by Wermink et al. (2015). However, Wingerden (2014) found that when accounting for the personal circumstances of the offender, such as housing, education, employment, relationships, and attitudes, the effects of citizenship become statistically insignificant.

Some of the discrepancies between the results of these studies might be due to their differing in many important methodological aspects, be it the dataset (including the period covered and the offences and/or types of courts considered), the variables they account for, or the multivariate regression models that are employed. However, it is also possible that they give a realistic account of the different pictures that exist in the various systems that were analysed.

\section{THE EUROPEAN PICTURE}

There is a significant lack of research on the issue of foreigners in European correctional institutions. Recent contributions by Ugelvik (2014), and Delgrande and Aebi (2009) are exceptions to this rule. However, data on foreign offenders may be found in various well-known datasets, such as the World Prison Brief and the Council of Europe's Space I and II.

The picture painted by this data and these accounts is not always a coherent or easily understandable one, as the following attempt shows. Table 1 presents various data on prisoners and foreigners in European countries. The first two columns thus tell a rudimentary story about the countries' level of punitiveness in 2016 - the first is the prison population rate (number of prisoners per 100,000 inhabitants) and the second is the absolute number of prisoners in a given country and offers a more realistic understanding of the actual size of the prison population. The third column shows the percentage of foreigners in prisons, a percentage that might be interesting to compare to the percentage of foreigners in the total population for 2017 in the fourth column. In the last two columns, the term "foreign" includes all persons whose citizenship is different from the country in which they are residing, whether they are there legally or not. 
Table 1: Data on foreigners in prison in European countries

\begin{tabular}{|c|c|c|c|c|}
\hline Title & $\begin{array}{c}\text { Prison } \\
\text { population } \\
\text { rate }\end{array}$ & $\begin{array}{c}\text { Prison } \\
\text { population total }\end{array}$ & $\begin{array}{c}\text { Foreign } \\
\text { Prisoners (\%) }\end{array}$ & $\begin{array}{c}\text { Foreign } \\
\text { population (\%) }\end{array}$ \\
\hline Monaco & 83.8 & 32 & 93.8 & $64.2^{*}$ \\
\hline Liechtenstein & 27 & 10 & 87.5 & $33.1^{*}$ \\
\hline Andorra & 60.1 & 47 & 78.7 & $56.9 *$ \\
\hline Luxembourg & 122.3 & 705 & 73.9 & 48.2 \\
\hline Switzerland & 83.0 & 6912 & 72.0 & 23.9 \\
\hline Austria & 101.5 & 8824 & 53.9 & 15.4 \\
\hline Greece & 89.3 & 9621 & 55.2 & $4.8(2016)$ \\
\hline Malta & 128.0 & 556 & 41.7 & $8.0^{*}$ \\
\hline Belgium & 102.7 & 11615 & 40.7 & 12.0 \\
\hline Cyprus & 78.7 & 668 & 41.5 & $18.2^{*}$ \\
\hline Norway & 73.9 & 3851 & 33.9 & 10.5 \\
\hline Estonia & 202.9 & 2670 & 38.4 & 16.2 \\
\hline Italy & 89.3 & 54195 & 33.8 & 8.5 \\
\hline Germany & 78.4 & 64397 & 35.6 & 12.2 \\
\hline Spain & 130.7 & 60687 & 28.5 & 9.5 \\
\hline Denmark & 59.7 & 3408 & 28.0 & 8.5 \\
\hline France & 102.6 & 68514 & 21.5 & 7.1 (2016) \\
\hline Sweden & 58.5 & 5762 & 21.3 & 8.6 \\
\hline Iceland & 37.3 & 124 & 21.0 & 9.0 \\
\hline Montenegro & 173.7 & 1081 & 18.8 & 8.2 \\
\hline Netherlands & 51.4 & 8726 & 18.2 & 5.7 \\
\hline Finland & 56.7 & 3110 & 17.5 & 4.4 \\
\hline Portugal & 133.2 & 13779 & 16.7 & 3.9 \\
\hline Ireland & 78.1 & 3688 & 12.7 & $12.9(2015)$ \\
\hline $\begin{array}{l}\text { UK: England \& } \\
\text { Wales }\end{array}$ & 146.4 & 85134 & 11.6 & 9.3 (UK) \\
\hline $\begin{array}{l}\text { UK: Northern } \\
\text { Ireland }\end{array}$ & 80.7 & 1500 & 9.1 & 9.3 (UK) \\
\hline Slovenia & 63.4 & 1308 & 9.0 & 7.3 \\
\hline
\end{tabular}




\begin{tabular}{|c|c|c|c|c|}
\hline Czech Republic & 213 & 22481 & 8.0 & 4.6 \\
\hline Croatia & 74.2 & 3108 & 6.1 & 17.6 \\
\hline $\begin{array}{c}\text { FYR } \\
\text { Macedonia }\end{array}$ & 161.7 & 3349 & 5.4 & 6.6 \\
\hline Hungary & 212.6 & 18171 & 5.0 & 1.6 \\
\hline $\begin{array}{c}\text { Russian } \\
\text { Federation } \neq\end{array}$ & 408 & 590635 & 4.3 & 0.8 (2016) \\
\hline UK: Scotland & 142.4 & 7657 & 3.9 & 9.3 (UK) \\
\hline Latvia & 212.6 & 4186 & 3.9 & $14.3^{*}$ \\
\hline Serbia & 150.7 & 10672 & 3.4 & $5.6^{*}$ \\
\hline Bulgaria & 116.7 & 8347 & 3.2 & $1.2^{*}$ \\
\hline $\begin{array}{c}\text { Bosnia and } \\
\text { Herzegovinał }\end{array}$ & 73 & 1722 & 2.6 & $0.6^{*}$ \\
\hline Turkey & 244.6 & 192627 & 2.2 & $5.8^{*}$ \\
\hline Slovakia & 187.6 & 10181 & 2.2 & 1.3 \\
\hline $\begin{array}{c}\text { BiH: Republika } \\
\text { Srpska }\end{array}$ & 74.6 & 863 & 2.0 & N/A \\
\hline Ukraine‡ & 157 & 56638 & 1.7 & $11.4^{*}$ \\
\hline Lithuania & 244.1 & 7051 & 1.5 & $4.9^{*}$ \\
\hline Albania & 204.8 & 5910 & 1.5 & $3.1^{*}$ \\
\hline Romania & 140.5 & 27765 & 1.1 & $0.9^{*}$ \\
\hline Poland & 188.4 & 71528 & 0.9 & $0.9^{*}$ \\
\hline
\end{tabular}

The main source for the table is the Council of Europe's Space I dataset for the year 2016 (Aebi, Tiago, Berger Kolopp, Burkhardt 2017). Data on countries marked by $\ddagger$ is taken from the World Prison Brief dataset (Institute for Criminal Policy Research 2018). Data on the percentage of foreigners (last column) is taken from the OECD's Report on international migration (OECD 2018), except for data marked by *, which is taken from the UN's Trends in International Migrant Stock, 2015 revision (UN Department of Economic and Social Affairs 2016).

While the first group of countries - i.e. Monaco, Liechtenstein, Andorra and Luxembourg - may be disregarded as statistically insignificant due to the low absolute numbers (Delgrande, Aebi 2009), at least there the high proportion of foreign prisoners somewhat correlates with the high proportion of the foreign population.

In a similar study, Ugelvik (2014) noticed a divide between west and east, which can be observed here as well. Focusing only on EU members, Ugelvik notes that the 'old west' averages over 26 percent of foreign prisoners in their prison populations, while in eastern Europe this percentage is as low as 3 percent on average. The phenomenon is also noted by Delgrande and Aebi (2009), who remind us that the 
divide is coterminous with the former Iron Curtain. Including more non-EU countries accentuates this division, as the Balkan countries, for example, fall well below the eastern EU average.

This picture coincides with the general notion of western countries having to deal with eastern criminals, a rhetoric continually employed in contemporary debates (e.g. Brexit). However, the proportion of people in prison has relatively little connection to crime rates in general and to foreign prisoners as well. Ugelvik (2014) illustrates this nicely using the example of Estonia, where the unexpectedly high proportion of foreign prisoners is due not to a huge influx of migrants but rather to a very restrictive citizenship granting policy.

The fact that Greece is among the top countries in Table 1 also does not fit into this generalised rhetoric, nor does the fact that the UK members feature towards the bottom half. Other explanations are needed to understand these phenomena - in the case of UK, a look at institutions housing migrants that are nominally not prisons, but essentially are not different from prisons (cf. Bosworth et al. 2016), might be a good way to search for such explanations.

\section{PUNISHING FOREIGNERS IN SLOVENIA}

With regard to sentencing and penality in general, Slovenia is somewhat of an outlier among its neighbours and has been termed "exceptional" in the Scandinavian sense (Dünkel 2013, 2017; Šelih, Završnik 2012). Its lenient sentencing policies have been present since before its independence in 1991 and have only started to recede in recent decades (Flander, Meško 2016; Plesničar 2013).

\section{Sentencing Foreign Offenders in General}

When analysing the punishing of foreigners, Ugelvik (2014: 117) notes that Slovenia is the "most 'western' of the eastern European countries", which puts it at the same level as the UK in terms of punishing foreigners. However, in the time since Ugelvik's assessment, some changes have occurred in Slovenia which may make it even more 'western' than some 'western European countries'.

Figure 1 shows that a relatively stable proportion of convicted foreigners has seen a steep rise in just one year, bringing it up to 22.6 percent of all convicted persons. This has also changed the makeup of Slovenian prisons, where about 18 percent of all prisoners are now foreigners (as in non-citizens), as shown in Figure 2. 
Figure 1: Citizens and non-citizens convicted by Slovenian courts in \%

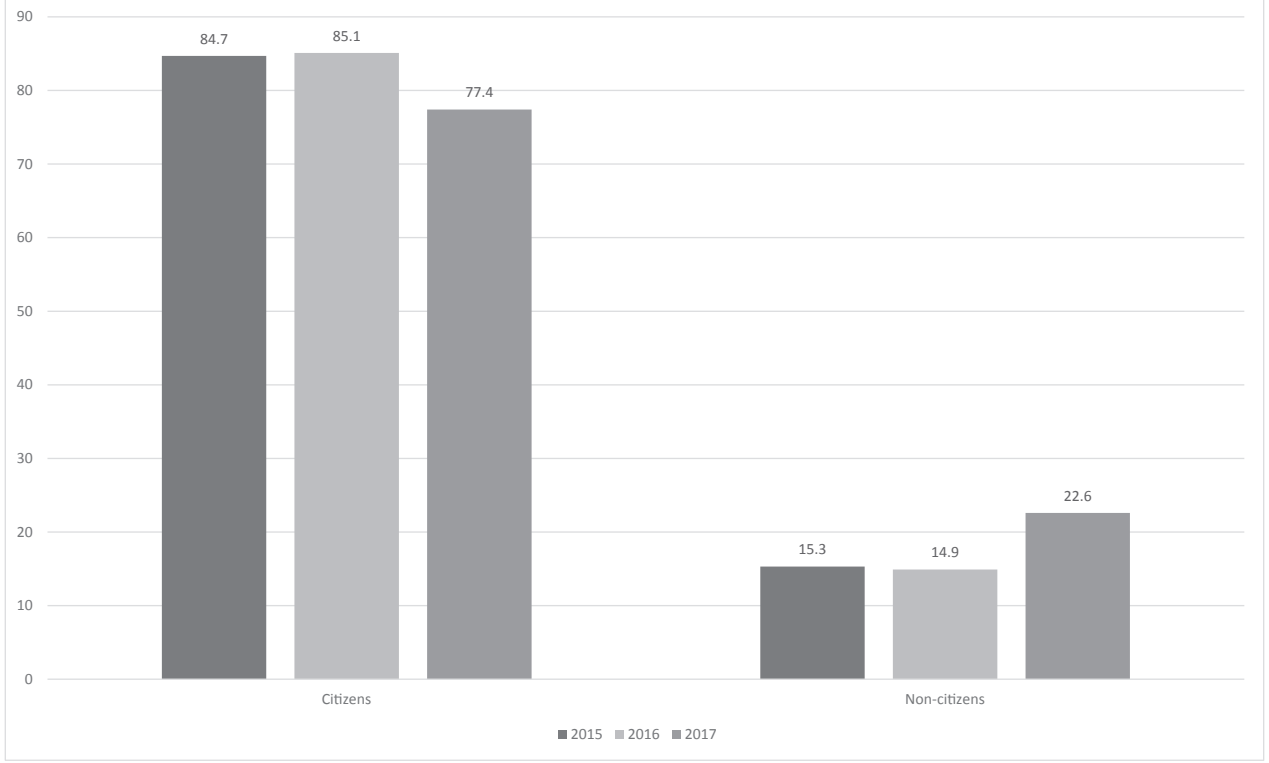

Source: Statistical Office of the Republic of Slovenia 2018

Figure 2: Proportion of non-citizens in Slovenian prisons in \%

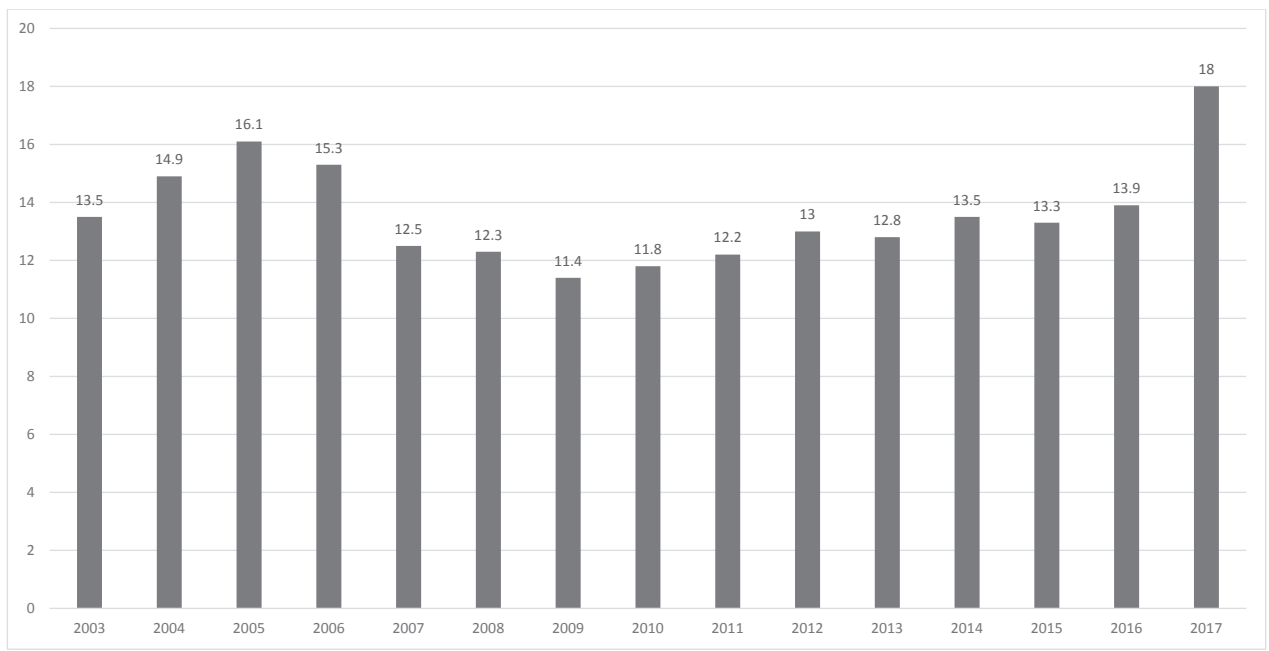

Source: Prison Administration of the Republic of Slovenia 2003-2018

However, the sudden rise cannot be attributed (only) to a changed attitude towards foreigners, but rather to a decrease in the incarceration of Slovenian citizens. As seen in Figure 3, the absolute number of foreigners has risen, but not to the extent that would explain the difference in the proportion of citizens vs foreign prisoners. 
Figure 3: Number of non-citizens in Slovenian prisons

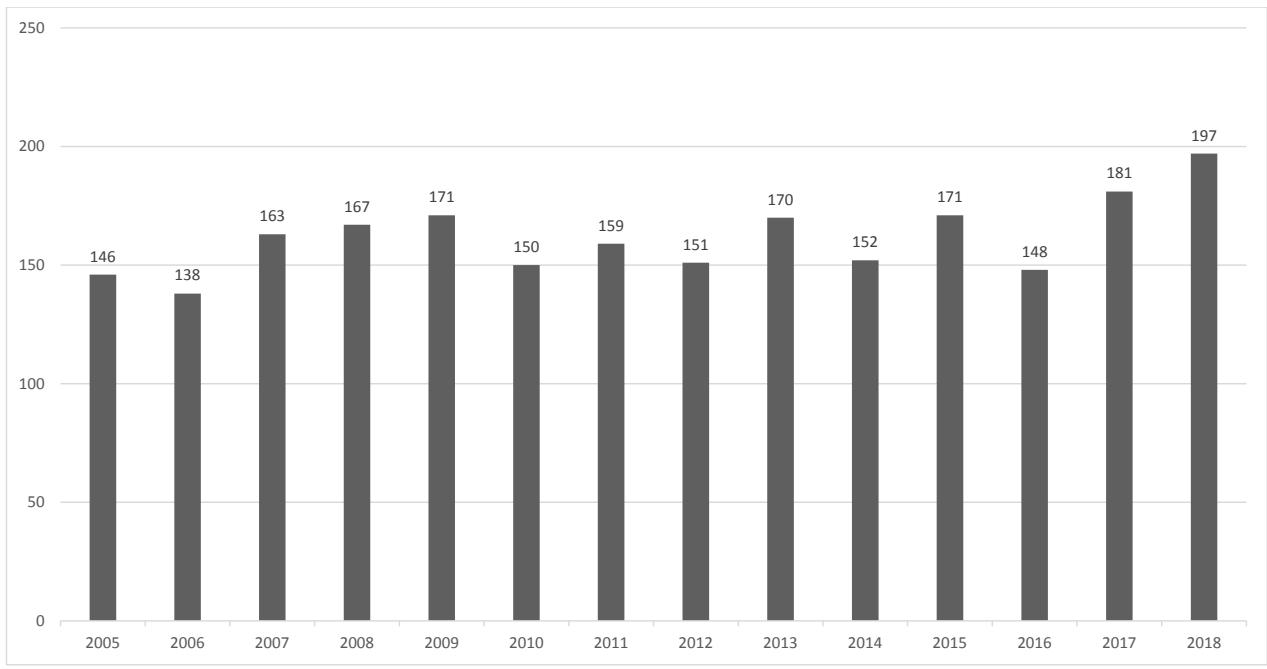

Source: Prison Administration of the Republic of Slovenia 2003-2018

In order to explain this occurrence, we would need much more data, which, however, turns out to be harder to obtain than expected. Data on convictions aggregated by citizenship has only been added to the Statistical Office's public dataset recently and is only available due to a change in methodology. Unfortunately, this means that such data is not available for prior years. Moreover, in order to understand the trend and its characteristics, it would be necessary to compare the number of convictions with the number of arrests and the number of charges brought against foreigners, which would again only be available for the last three years. Sadly, this data is also not yet publicly available, and the Statistical Office was not able to provide it before publication. These missing data would perhaps explain at what stage of the criminal proceedings the upward trend begins, as well as when exactly it began.

Data on convictions reflects changes in the last year, but due to the length of criminal proceedings in Slovenia, it is safe to assume that the criminal offences in question occurred two to three years ago. This would coincide with the rhetoric offered by the right-wing political factions, claiming that the spikes in migration in 2015 (Kogovšek Šalamon 2017) caused a rise in crime rates. However, such a proposition is easily refuted just by looking at the data on convicted foreigners and their countries of origin (Table 2). 
Table 2: Countries of origin of convicted non-citizens

\begin{tabular}{|c|c|c|c|}
\hline & 2015 & 2016 & 2017 \\
\hline Bosnia and Herzegovina & 301 & 289 & 531 \\
\hline Kosovo & 92 & 83 & 186 \\
\hline Croatia & 130 & 91 & 175 \\
\hline FYR Macedonia & 108 & 130 & 145 \\
\hline Serbia & 175 & 129 & 124 \\
\hline Bulgaria & 44 & 49 & 69 \\
\hline Albania & 54 & 12 & 18 \\
\hline Italy & 35 & 35 & 18 \\
\hline Hungary & 72 & 12 & 18 \\
\hline Romania & 97 & 24 & 16 \\
\hline Slovakia & 11 & 9 & 16 \\
\hline Ukraine & 18 & 18 & 14 \\
\hline Montenegro & 20 & 26 & 13 \\
\hline Germany & 2 & 7 & 12 \\
\hline China & 3 & 15 & 3 \\
\hline USA & 2 & 18 & 0 \\
\hline Other countries & 53 & 51 & 56 \\
\hline
\end{tabular}

Source: Statistical Office of the Republic of Slovenia 2018

As Table 2 shows, the vast majority in the absolute numbers, as well as the largest increase, resulted from the convicting of foreign citizens of countries of the former Yugoslavia. The proportion between them and other countries has not changed, and the stereotypical 'illegal alien' as the personification of otherness and danger as discussed above does not feature among the top 15 countries of origin at all. In fact, the last category, 'Other countries', features countries from all over the world, but none of them exceeds ten offenders in any given year.

We could also try to explain the rise in the proportion of convicted and imprisoned persons with any of the theories mentioned above when discussing the differential treatment of offenders. However, it is unlikely that any of them would cause such a dramatic upturn, as they focus on patterns and trends in decision-making that are deeply ingrained and less prone to sudden changes.

Moreover, the possibility of a more lenient treatment of citizens when compared to foreigners (Delgrande, Aebi 2009) is also a dubious hypothesis. Firstly, the sudden change makes such an explanation less likely, but more importantly there is an oddity about it that requires explanation. As mentioned, there has been a drop in the absolute numbers and in the proportion of convicted and imprisoned Slovenian 
citizens. What makes it even more curious, however, is the fact that the drop only features in the male prison population, while the number and proportion of women in Slovenian prisons is on the rise (Plesničar 2018).

On the other hand, we might try to invoke procedural changes, mainly the introduction of plea bargaining in 2012, as a potential cause for the trend in punishing foreigners, but a definitive answer would require a thorough and detailed analysis of how this affects citizens vs non-citizens.

What is certain, however, is that Slovenia's treatment of foreigners has undergone a significant change, but it is perhaps too early to try to explain it. It will be interesting to observe how the trend develops in the future and to combine that with additional data that will perhaps become available in the meantime.

\section{Sentencing Homicide Offenders}

Faced with so much missing data on general convictions, we turned to an existing dataset, in which we analysed court judgments in cases of homicide and attempted homicide. The analysis is based on a database of about 500 homicide cases from the period 1991-2016, which represent all available cases taken from all Slovenian District Courts. We felt that an analysis of homicide with regard to foreigners would fit well into current public debates on the 'violent foreigner'. Moreover, homicides typically do not go unreported and the clearance rate (i.e., the rate at which the police successfully solve crimes) in these criminal offences is very high $(100 \%$ in the last few years according to police data), which enables us to analyse the bulk of all cases and to escape the pitfalls of the dark spectre of criminality.

Homicide in Slovenia is typically a very personal matter. Almost half of all homicide cases involve the defendant's family members and intimate partners as victims; the rest are committed against neighbours, friends, acquaintances, and less than ten percent against strangers (Plesničar, Hafner 2015).

We analysed both questions of citizenship and ethnicity in this dataset in order to shed some light on the previously discussed issue of varying degrees of foreignness. This is typically extremely difficult to analyse, as Slovenia does not systematically collect data on ethnicity in relation to criminal justice. However, court judgments were fertile ground for research, as it is standard procedure for courts to state the defendant's ethnicity in the "general part", i.e. introductory section, of the judgment. There are no formal requirements or definitions of how this data is to be collected, but in the majority of cases, judges rely on the information given by the defendant. Given that systematically collecting such data would be frowned upon as potentially unconstitutional, it is interesting that judges still follow the tradition in their judgments. 
Figure 4: Citizenship of defendants in homicide cases in \%

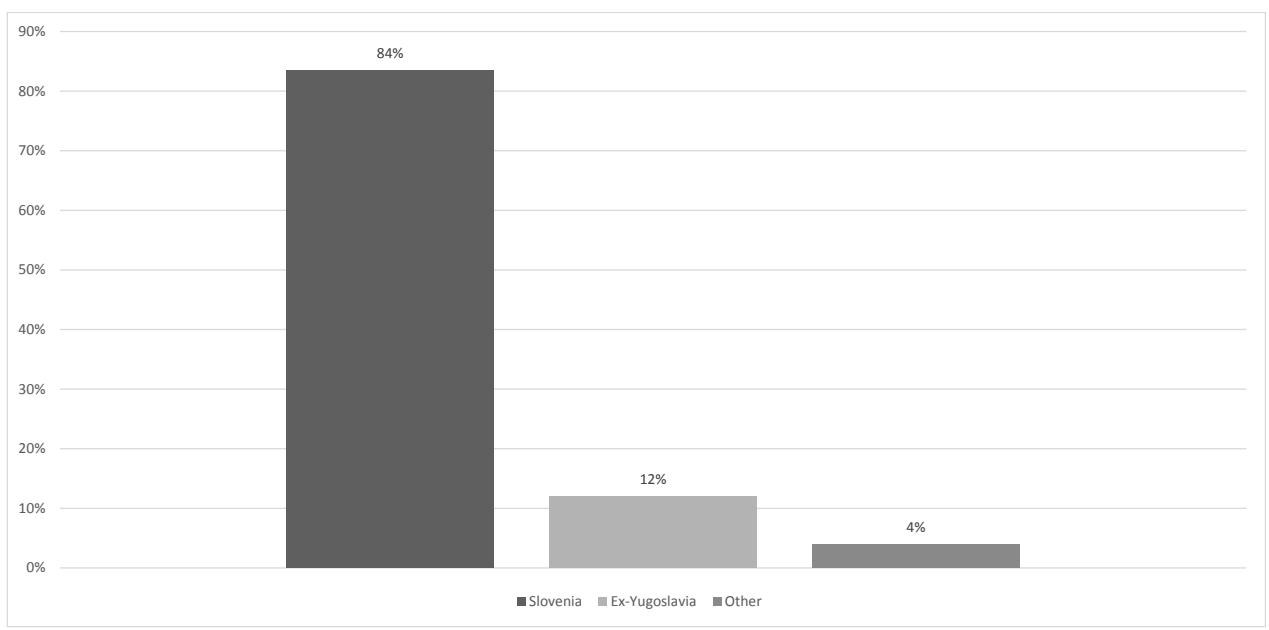

Figure 5: Ethnicity of defendants in homicide cases in \%

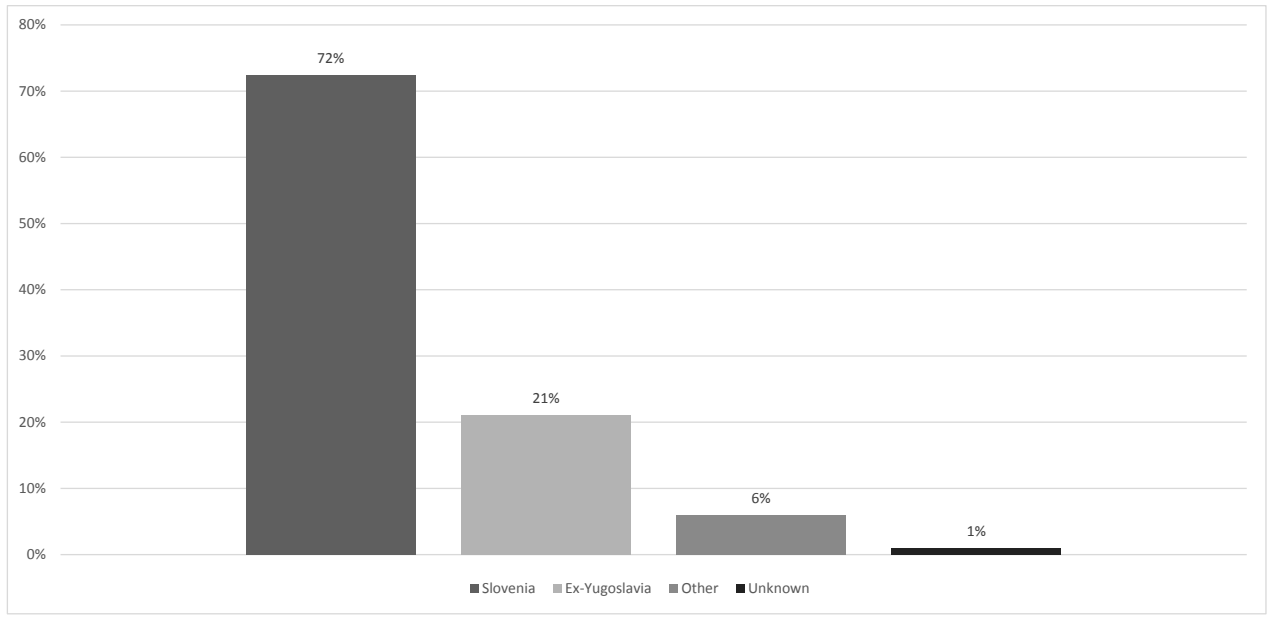

What we can see from figures 4 and 5 is that the proportion of foreign nationals is significantly larger than the proportion of foreign citizens. Of the 510 cases analysed, 84 involved a defendant with foreign citizenship, while 139 defendants were of foreign ethnicity (with or without Slovenian citizenship). Moreover, when trying to assess their immigration status, we discovered that $17 \%$ of foreign national defendants were first-generation immigrants (defined as born abroad), while 4\% were second-generation immigrants (born in Slovenia to foreign national parents).

When looking at sentences that defendants received for the offences, the picture becomes even fuzzier. A preliminary data analysis suggests that the differences in sentences between citizens and non-citizens are contrary to expectations. It appears 
that in general, foreign offenders have received lower prison sentences than Slovenian citizens. When the category of foreigners is further dissected, it appears that citizens of Ex-Yugoslavian countries on average receive shorter sentences than other foreign citizens and Slovenian citizens (Figure 6). The pattern seems to be repeated with regard to ethnicity as well (Figure 7).

Figure 6: Average prison sentence for homicide offenders in years according to citizenship (preliminary data)

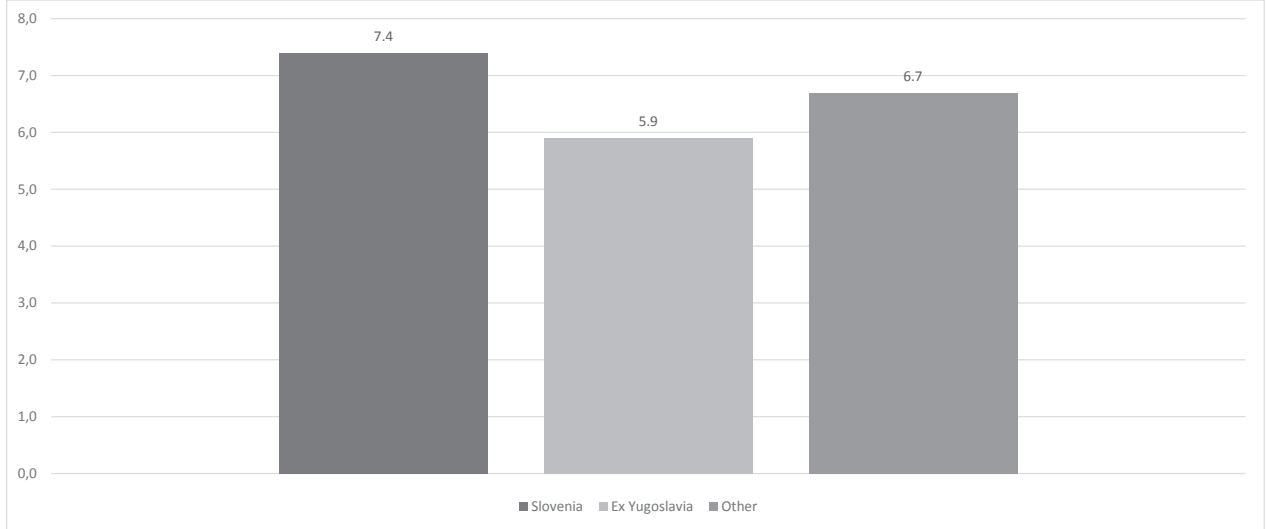

Figure 7: Average prison sentence for homicide offenders in years according to ethnicity (preliminary data)

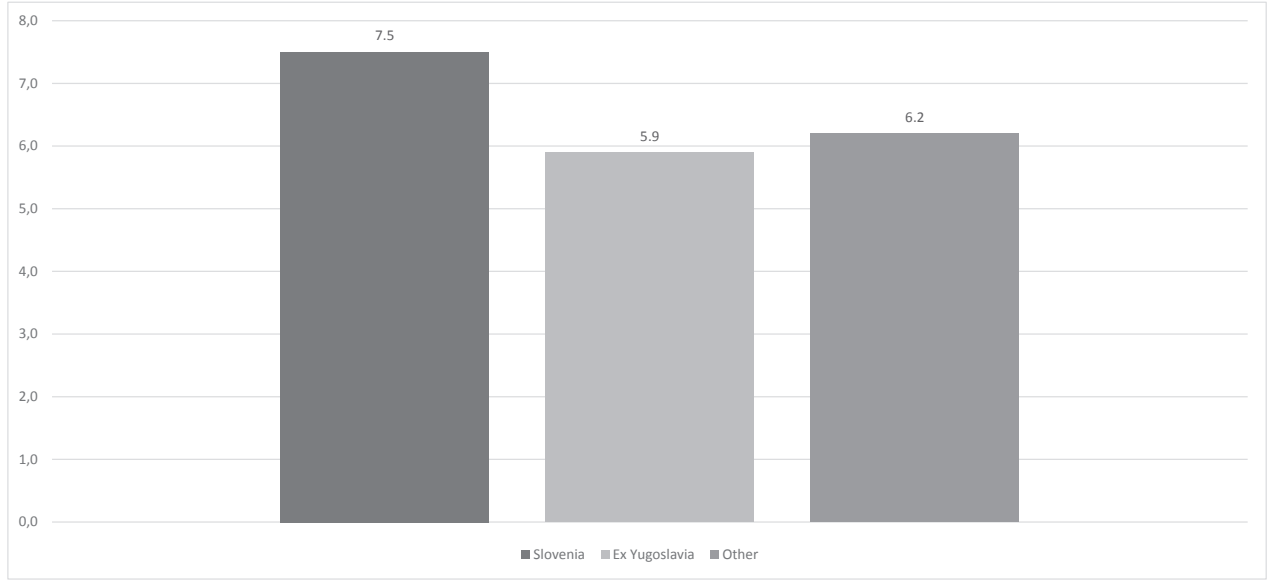

This preliminary data is curious and requires further attention and scrupulous analysis. One potential caveat might be that the total number of cases is relatively low, which is even more true for the number of cases with foreign offenders. Moreover, homicide is a specific crime that in many ways differs significantly from other, more 
common criminal offences, and unexpected results might be more indicative of these differences than of general trends.

In trying to look for the rationale for these data, we have identified several potential explanations. Firstly, Slovenia has had the option of deportation either as a criminal sanction in addition to imprisonment or as a potential legal consequence of imprisonment. It would be plausible to think courts might choose this option to relieve the system of foreign offenders. However, it has rarely been used (even) in cases of homicide: in the entire period, only 13 deportation orders were mandated.

Next, there is the question of the victims. As stated earlier, the majority of homicides in Slovenia occur among family members, friends and acquaintances. This is also true for homicides committed by foreign offenders. Courts are not as meticulous about determining the victim's citizenship and ethnicity as they are with defendants, therefore the data we gathered was sometimes based on a circumstantial assessment of citizenship or ethnicity. However, what seems apparent is that when foreign offenders have committed homicide, their victims were somewhat less likely to be Slovenian or, at least, it was harder to determine their citizenship or ethnicity. This could lead to a less engaged judiciary, who might be less likely to empathize with victims. However, when discussing homicide this might be a slippery argument and would need further analysis to be proven.

Furthermore, Slovenian courts are lenient when compared to their counterparts in many other systems, which is true even though their leniency is less pronounced every year (Flander, Meško 2016). Moreover, they are relatively loosely restrained by statutory sentencing guidelines and free to decide on mitigating and aggravating circumstances in each individual case (Plesničar 2013). In some instances, the reasons given by the courts for individual sentences contained rationalizations in terms of socio-cultural differences. These were used to absolve the defendant's behaviour, which could potentially account for a proportion of the differences in sentences we see in the data. However, a thorough textual analysis would be needed to put forward this theory with serious plausibility.

Lastly, it seems very likely that Wingerden's finding in the Dutch context would be applicable in Slovenia as well. Wingerden (2014) found that when Dutch offenders' characteristics such as housing, education, employment, relationships and attitudes are considered, the effects of citizenship become statistically insignificant. A thorough analysis of all relevant data for Slovenia might likely prove little effect of citizenship on the sentencing decision.

In conclusion, it is important to point out that the analysis included cases ending in 2015/2016 and hence did not cover the latest upturn in foreign convictions and imprisonments discussed earlier. Nevertheless, even though the data show an increase in the proportion of convicted foreign offenders in almost all types of criminal offences, including violent crime (Figure 8), homicide seems to be an exception. Of the 60 homicide cases that resulted in a conviction in the past three years, only four were committed by foreigners (Figure 9 ). 
Figure 8: Non-citizens convicted by Slovenian courts for offences chapters in \%

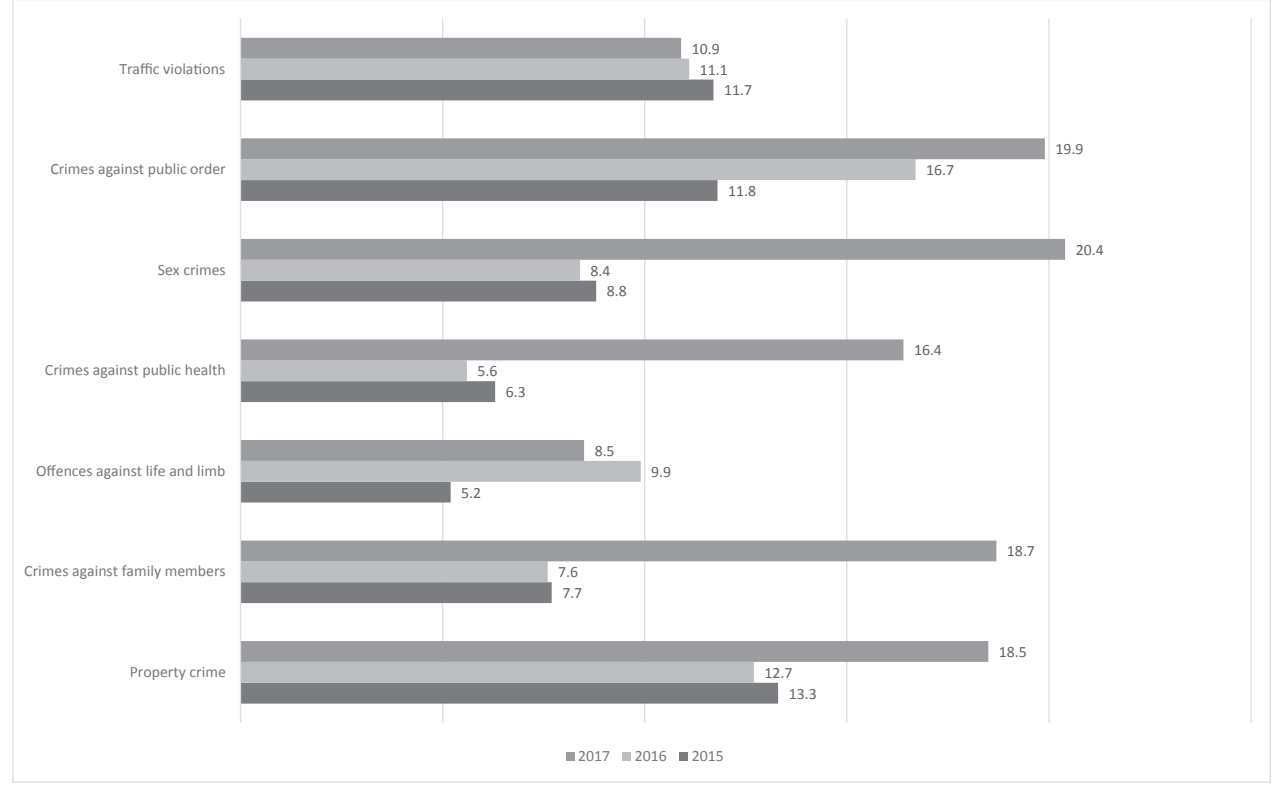

Source: Statistical Office of the Republic of Slovenia 2018

Figure 9: Defendants convicted of homicide by citizenship

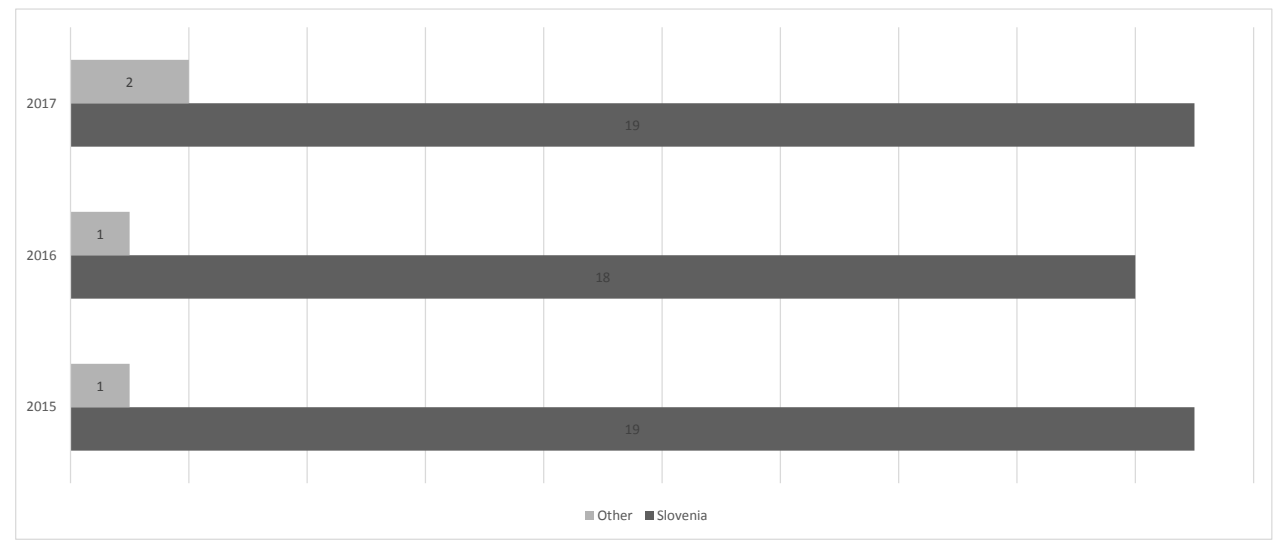

Source: Statistical Office of the Republic of Slovenia 2018 


\section{CONCLUSION}

It has become clear throughout the drafting of this paper that we know too little about the intersection of criminal justice and foreignness. While we have theoretical presentations of concepts and ideas, and we have some empirical accounts of what happens in practice, the two are not necessarily aligned and coherent.

The analysis of foreign offenders in the Slovenian context is a good example of this conundrum. While the general trend fits with accounts of demonizing the foreigner (Melossi 2003; Wacquant 1999), and even more so in the contemporary crimmigration context, a detailed look offers a fuzzier picture. Questions of who is and who is not a foreigner are not merely theoretical exercises, but practical issues with tangible consequences. Slovenia's entanglement with the Ex-Yugoslav countries and the many people who have left them for life in Slovenia means that the criteria as to what being foreign means are less clear and not merely a question of citizenship. It soon becomes clear, however, that foreignness is not a uniform question, but rather a continuum with non-foreignness on one side and complete foreignness on the other, and a plethora of possible interpretations in between.

Moreover, a more detailed look into just one aspect of sentencing foreigners, for the offence of homicide, has revealed a whole set of dilemmas and contradictions. The results that point towards a more lenient punishment of foreigners are rather surprising, and while we have offered some possible explanations, we claim no definitive answer. More research is needed to see whether homicide is an anomaly or whether such a trend is overarching. Regardless of the answer, the fact that we have to pose the question shows that some assumptions made on the general level may be questionable or outright wrong when dealing with the details. This is, after all, where the proverbial devil is to be found. We are, however, very unlikely to find it unless we actively search for it, which means that there is an abundance of research to be made in the field of criminal justice as it intersects with foreignness.

In terms of future research, seeking different notions of what 'foreignness' means in different countries and societies would improve our knowledge and enrich theoretical accounts of "otherness" in relation to criminology. This would call for not merely quantitative, but rather qualitative analyses, preferably in various settings and with a comparable value. Moreover, degrees of 'foreignness' might be a better measure of differences and disparities in the criminal justice treatment and outcomes than currently researched notions of citizenship, ethnicity and perhaps even race. This suggestion would need to be tested, and we believe more empirical data on the punishment of foreigners in different countries would take us some way towards that end. 


\section{REFERENCES}

Aebi, Marcelo F., Tiago, Melanie M., Berger Kolopp, Lea, Burkhardt, Christine (2017). SPACE I - Council of Europe Annual Penal Statistics: Prison Populations. Survey 2016. Strasbourg: Council of Europe.

Albonetti, Celesta A. (1991). An Integration of Theories to Explain Judicial Discretion. Social Problems 38/2, 247-266.

Albonetti, Celesta A. (1997). Sentencing under the Federal Sentencing Guidelines:

Effects of Defendant Characteristics, Guilty Pleas, and Departures on Sentence Outcomes for Drug Offenses, 1991-1992. Law \& Society Review 31/4, 789.

Bauman, Zigmund (1997). Postmodernity and its Discontents. Cambridge: Polity Press. Blalock, Hubert M. (1967). Toward a Theory of Minority-Group Relations. New York: Wiley. Bosworth, Mary, Hasselberg, Ines, Turnbull, Sarah (2016). Punishment, Citizenship and Identity: An Introduction. Criminology \& Criminal Justice 16/3, 257-266.

Bridges, George S., Crutchfield, Robert D., Simpson, Edith E. (1987). Crime, Social Structure and Criminal Punishment: White and Nonwhite Rates of Imprisonment. Social Problems 34/4, 345-361.

Bučar Ručman, Aleš (2015). Migracije in kriminaliteta: Pogled čez meje stereotipov in predsodkov. Ljubljana: ZRC SAZU.

Caldwell, Beth (2016). The Demonization of 'Criminal Aliens', http://crimmigration. com/2016/10/25/the-demonization-of-criminal-aliens/ (7. 8. 2018).

Delgrande, Natalie, Aebi, Marcelo F. (2009). Les détenus étrangers en Europe: Quelques considérations critiques sur les données disponibles de 1989 à 2006. Déviance et Société 33/4, 475-499.

Demuth, Stephen (2002). The Effect of Citizenship Status on Sentencing Outcomes in Drug Cases. Federal Sentencing Reporter 14/5, 271-275.

Dünkel, Frieder (2013). Slovenian Exceptionalism?-Die Entwicklung von Gefangenenraten im internationalen Vergleich. Essays in Honour of Alenka Šelih: Criminal Law, Criminology, Human Rights. Ljubljana: Institute of Criminology, 61-93.

Dünkel, Frieder (2017). European Penology: The Rise and Fall of Prison Population Rates in Europe in Times of Migrant Crises and Terrorism. European Journal of Criminology 14/6, 629-653.

Engen, Rodney L., Steen, Sara, Bridges, George S. (2002). Racial Disparities in the Punishment of Youth: A Theoretical and Empirical Assessment of the Literature. Social Problems 49/2, 194-220.

Everett, Ronald S., Wojtkiewicz, Roger A. (2002). Difference, Disparity, and Race/Ethnic Bias in Federal Sentencing. Journal of Quantitative Criminology 18/2, 189-211.

Fishman, Gideon, Rattner, Arye, Turjeman, Hagit (2006). Sentencing Outcomes in a Multinational Society: When Judges, Defendants and Victims Can Be either Arabs or Jews. European Journal of Criminology 3/1, 69-84. 
Flander, Benjamin, Meško, Gorazd (2016). Penal and Prison Policy on the "Sunny Side of the Alps": The Swan Song of Slovenian Exceptionalism? European Journal on Criminal Policy and Research, 1-27.

Fontaine, Gary, Emily, Catherine (1978). Causal Attribution and Judicial Discretion: A Look at the Verbal Behaviour of Municipal Court Judges. Law and Human Behaviour 2/4, 323-337.

Franko, Katja (2007). Globalization and Crime. London: Sage Publications Ltd.

Franko, Katja (2014). Bordered Penality: Precarious Membership and Abnormal Justice. Punishment \& Society 16/5, 520-541.

Franko, Katja, Bosworth, Mary (eds.) (2013). The Borders of Punishment: Migration, Citizenship, and Social Exclusion. Oxford, United Kingdom: OUP Oxford.

Garland, David (2001). The Culture of Control: Crime and Social Order in Contemporary Society. Oxford: Oxford University Press.

Hartley, Richard D., Armendariz, Luisa F. (2011). Border Justice? Sentencing Federal Narcotics Offenders in Southwest Border Districts: A Focus on Citizenship Status. Journal of Contemporary Criminal Justice 27/1, 43-62.

Hawkins, Darnell F. (1981). Causal Attribution and Punishment for Crime. Deviant Behaviour 2/3, 207-230.

Hernandez, Cesar C. G. (2014). Creating Crimmigration. Brigham Young University Law Review 2013/6, 1456-1516.

Hernandez, Cesar C. G. (2015). Crimmigration Law. American Bar Association.

Holmberg, Lars, Kyvsgaard, Britta (2003). Are Immigrants and Their Descendants Discriminated against in the Danish Criminal Justice System? Journal of Scandinavian Studies in Criminology and Crime Prevention 4/2, 125-142.

Hudson, Barbara (2003). Justice in the Risk Society: Challenging and Re-Affirming Justice in Late-Modernity. London: Sage.

Hudson, Barbara (2006). Punishing Monsters, Judging Aliens: Justice at the Borders of Community. Australian \& New Zealand Journal of Criminology 39/2, 232.

Institute for Criminal Policy Research (2018). World Prison Brief. London: Institute for Criminal Policy Research.

Johnson, Brian D., Van Wingerden, Sigrid, Nieuwbeerta, Paul (2010). Sentencing Homicide Offenders in the Netherlands: Offender, Victim, and Situational Influences in Criminal Punishment. Criminology 48/4, 981-1018.

Kogovšek Šalamon, Neža (2016). Erased. Frankfurt am Main: Peter Lang AG.

Kogovšek Šalamon, Neža (2017). Mass Migration, Crimmigration and Defiance. Southeastern Europe 41/3, 251-275.

Light, Michael T., Massoglia, Michael, King, Ryan D. (2014). Citizenship and Punishment: The Salience of National Membership in U.S. Criminal Courts. American Sociological Review 79/5, 825-847.

Lombroso, Cesare, Ferrero, Giuglielmo (2004). Criminal Woman, the Prostitute, and the Normal Woman (eds. Nicole H. Rafter, Mary Gibson). Durham: Duke University Press. 
Melossi, Dario (2003). 'In a Peaceful Life': Migration and the Crime of Modernity in Europe/Italy. Punishment \& Society 5/4, 371-397.

Mitchell, Ojmarrh (2005). A Meta-Analysis of Race and Sentencing Research: Explaining the Inconsistencies. Journal of Quantitative Criminology 21/4, 439-466.

Mustard, David B. (2001). Racial, Ethnic, and Gender Disparities in Sentencing: Evidence from the U.S. Federal Courts. The Journal of Law and Economics 44/1, 285-314.

OECD (2018). International Migration Outlook 2018. Paris: OECD Publishing.

Plesničar, Mojca M. (2013). The Individualization of Punishment: Sentencing in Slovenia. European Journal of Criminology 10/4, 462-478.

Plesničar, Mojca M., Hafner, Miha (2017) Sentencing Those who Kill: Patterns and Trends in Sentencing for Homicide in Slovenia in the Past 25 years, EUROCRIM 2017. Cardiff: European Society of Criminology.

Prison Administration of the Republic of Slovenia (2003-2018). Letno poročilo (Annual Report), available at: http://www.mp.gov.si/si/o_ministrstvu/ursiks_organ_v_ sestavi/dokumenti/letna_porocila/

Quinney, Richard (1973). Critique of Legal Order: Crime Control in Capitalist Society. Boston: Little, Brown and Co.

Statistical Office of the Republic of Slovenia (2018). Dataset on Crime, available at: https://pxweb.stat.si/pxweb/Database/Dem_soc/Dem_soc.asp

Šelih, Alenka, Završnik, Aleš (2012). Crime and Transition in Central and Eastern Europe. New York: Springer Science \& Business Media.

Shaver, Kelly G. (1975). An Introduction to Attribution Processes. Cambridge, Mass: Winthrop Publishers.

Spohn, Cassia (2013). The Effects of the Offender's Race, Ethnicity, and Sex on Federal Sentencing Outcomes in the Guidelines Era. Law and Contemporary Problems 76, 75-104.

Steffensmeier, Darrell, Demuth, Stephen (2000). Ethnicity and Sentencing Outcomes in U.S. Federal Courts: Who is Punished More Harshly? American Sociological Review 65/5, 705.

Steffensmeier, Darrell, Kramer, John, Streifel, Cathy (1993). Gender and Imprisonment Decisions. Criminology 31/3, 411-446.

Steffensmeier, Darrell, Ulmer, Jeffery, Kramer, John (1998). The Interaction of Race, Gender, and Age in Criminal Sentencing: The Punishment Cost of Being Young, Black, and Male. Criminology 36/4, 763-798.

Stumpf, Juliett P. (2006). The Crimmigration Crisis: Immigrants, Crime, and Sovereign Power. American University Law Review 56, 367.

Tajfel, Henry, Turner, John (1979). An Integrative Theory of Intergroup Conflict. The Social Psychology of Intergroup Relations (eds. William G. Austin, Stephen Worchel. Monterey, Calif: Brooks/Cole Pub. Co.

Ugelvik, Thomas (2014). The Incarceration of Foreigners in European Prisons. The Routledge Handbook on Crime and International Migration (eds. Sharon Pickering, Julie Ham). London: Routledge. 
UN Department of Economic and Social Affairs (2016). Trends in International Migrant Stock: The 2015 revision. New York: United Nations.

United States Sentencing Commission. (2010). Demographic Differences in Federal Sentencing Practices: An Update of the Booker Report's Multivariate Regression Analysis.

Vezovnik, Andreja (2017). Otherness and Victimhood in the Tabloid Press: The Case of the "Refugee Crisis" in "Slovenske novice". Dve Domovini / Two Homelands 45, 121-136.

Vincenzi, Christoper (1985). The Aliens Act 1905. New Community 12/2, 275-284.

Wacquant, Louis (1999). 'Suitable Enemies': Foreigners and Immigrants in the Prisons of Europe. Punishment \& Society 1/2, 215-222.

Welch, Michael, Schuster, Liza (2005). Detention of Asylum Seekers in the UK and USA: Deciphering Noisy and Quiet Constructions. Punishment Society 7/4, 397-417.

Welch, Susan, Spohn, Cassia, Gruhl, John (1985). Convicting and Sentencing Differences among Black, Hispanic, and White Males in Six Localities. Justice Quarterly 2/1,67-80.

Wermink, Hilde, Johnson, Brian D., Nieuwbeerta, Paul, de Keijser, Jan W. (2015). Expanding the Scope of Sentencing Research: Determinants of Juvenile and Adult Punishment in the Netherlands. European Journal of Criminology 12/6, 739-768.

Wingerden, Sigrid van (2014). Sentencing in the Netherlands: Taking Risk-Related Offender Characteristics into Account. The Hague, the Netherlands: Eleven International Publishing.

Wolfe, Scott E., Pyrooz, David C., Spohn, Cassia C. (2011). Unraveling the Effect of Offender Citizenship Status on Federal Sentencing Outcomes. Social Science Research 40/1, 349-362.

Wu, Jawjeong, D'Angelo, Jill M. (2014). Unwarranted Disparity in Federal Sentencing: Noncitizen Crime as a Social/Group Threat. Criminal Justice Review 39/1, 58-80.

Wu, Jawjeong, Spohn, Cassia (2010). Interdistrict Disparity in Sentencing in Three U.S. District Courts. Crime \& Delinquency 56/2, 290-322. 


\section{POVZETEK}

\section{KAZNOVANJE TUJCEV: KAZNOVANJE TUJIH STORILCEV KAZNIVIH DEJANJ V SLOVENIJI Mojca M. PLESNIČAR, Jaka KUKAVICA}

Prispevek se ukvarja z obravnavo tujcev v kazenskopravnih sistemih, ki so je deležni kot storilci kaznivih dejanj, in ne v sodobnem kontekstu kriminalizacije migracij. Uvodoma avtorja odstirata nianse «tujosti«, koncepta, ki zajema veliko več kot le vprašanje državljanstva. V sodobnih družbah tako obstajajo različne oblike tujosti, glede njih pa je mogoče vleči vsebinske vzporednice s sodobnimi razpravami o »drugem« $v$ kriminološkem kontekstu. Strah pred drugimi je v veliki meri tako mogoče primerjati s strahom pred tujci - ki se bodisi rasno, etnično, versko ali drugače razlikujejo od večine. V kazenskopravnem sistemu se tovrstni »drugi« pojavljajo pogosteje, kot bi bilo glede na njihovo zastopanost v širši družbi mogoče pričakovati, pri čemer je temeljna raziskovalna dilema predvsem vprašanje, od kod te razlike izhajajo: so sad kriminalitete ali diskriminacije? Zdi se, da empirične študije iz različnih okolij potrjujejo predvsem slednje.

Tudi v evropskem prostoru je tako $v$ zaporih mogoče zaznati pomemben delež tujcev, pri čemer je mogoče razlikovati med različnimi skupinami držav. V glavnem je opazna ločnica med t. i. zahodom in vzhodom: prvi je predvsem deležen imigracij in se sooča z visokim deležem tujcev $v$ zaporih, drugi pa je predvsem deležen emigracij in zaznava nižji delež tujcev $v$ zaporih. Vendar slika ni enoznačna in izjeme od te splošne porazdelitve lahko postavijo na glavo delitev samo.

Slovenija se v tem kontekstu umešča med bolj »zahodne« med »vzhodnimi« državami, predvsem pa je zanjo značilen nepojasnjeno velik porast deleža tujcev med zaprtimi osebami. Podrobnejši pogled pokaže, da gre $v$ državi v resnici za pomemben padec deleža moških državljanov, medtem ko je trend zviševanja opazen pri tujcih in ženskah.

Podrobnejša analiza kaznivih dejanj umora in uboja v Sloveniji pa pokaže, da so tujci pri teh kaznivih dejanjih v splošnem deležni celo nekoliko manj strogih sankcij kot slovenski državljani, kar še zlasti velja za tujce, ki izhajajo iz držav nekdanje Jugoslavije. Ugotovitev je mogoče pojasnjevati na več načinov, gotovo pa bo potrebna še natančnejša analiza. 